\title{
China's Participation in the Global Ocean Governance Reform: Its Lessons and Future Approaches
}

\author{
Zewei Yang**
}

Global ocean governance is a historical product. In the course of development, the UNCLOS has established the contemporary global ocean governance system. The current system, however, has many defects, including ambiguity in rules and fragmentation in structure. Furthermore, some new challenges are ever-emerging in the system. But all these could be improved through the establishment of a UNCLOS review agency and an enactment of supplementary agreements. China has taken lessons from its participation in the development and reform of the system. This includes the creation of the identity of a developing country, being an active participant and promoter of change as opposed to being a passive recipient and follower inside the system. In its push for reforming global ocean governance, China should not only initiate the establishment of a "World Ocean Organization," but also enhance its agenda setting, drafting and contracting capabilities of international legislation.

\section{Keywords}

Global Ocean Governance, UNCLOS, China, World Ocean Organization

With the increase of China's strength, the interaction between China and the existing multilateral system has become more complex: On the one hand, China has joined the multilateral system extensively, seeking a greater voice in it. On the other

* This article is a part of the results of a research project, "Study on International Legal Issues of Safeguarding China's National Rights and Interests" (Project No.17JJD820006), a Key Project of Philosophy and Social Science Research, sponsored by the Ministry of Education, P.R. China.

** Luojia Distinguished Professor of International Law Institute, China Institute of Boundary and Ocean Studies, and Collaborative Innovation Center for Territorial Sovereignty and Maritime Rights at Wuhan University. A.B.(Hunan Normal Univ.), M.A./Ph.D.(Wuhan). ORCID: http://orcid.org/0000-0001-9937-2741. The author may be contacted at: fxyyzw@whu.edu.cn / Address: Luojia Hill, Wuhan, Hubei Province, 430072, P.R. China.

DOI: http://dx.doi.org/10.14330/jeail.2018.11.2.03 
hand, China has tried to create a new multilateral system to realize its national interests, such as the creation of the Asian Infrastructure Investment Bank, BRICS Bank, etc.

Robert Keohane ${ }^{1}$

\section{Introduction}

China is not a country with a favorable marine geography. However, it is a burgeoning state with huge marine capacity with the third largest shipping fleet and the largest shipbuilding caliber in the world. ${ }^{2}$ As a leading maritime power, China has a real need for global ocean governance reform. ${ }^{3}$ This will help China protect its maritime interests and improve its influence in the global ocean governance. ${ }^{4}$ A study on the historical evolution of the global ocean governance system and its contemporary condition is indispensable for today's China.

This research is to sum up China's lessons from history in establishing a global ocean governance system and to explore the ways of China's active participation in the reform process. This paper is composed of five parts including this Introduction and a Conclusion. Part two will criticize the contemporary global ocean governance system, scrutinize main challenges and development trends, and suggest improvements. Part three will review China's participation in the global ocean governance reform. Part four will illustrate China's institutional design for the reform.

1 R. Keohane, Competitive Multilateralism and the Rise of China, 6 Foreign Aff. 20 (2015). See also J. Morse \& R. Keohane, Contested Multilateralism, 9 Rev. INT'L Org. 385-412 (2014).

2 As of 2018, the capacity of port cargo and container handling of China has remained in first place of the world for nine consecutive years. In 2010, China became the world's top shipbuilding and port machinery manufacturing country. The development of China's ocean engineering equipment (such as HYSY-981, Jiaolong deep-sea manned submersible) has also attracted the attention of the world. See Peiju Yang, The Voice of China in Maritime World, 8 CHINA SHIP Surv. (2012).

3 The 18th CPC National Congress clearly reported that China should "improve the capacity of marine resources development, develop the marine economy, protect the marine ecological environment, firmly safeguard the national marine rights and interests, and build a powerful marine power." See Jintao Hu, Unswervingly Follow the Path of Socialism with Chinese Characteristics and Strive for a Moderately Prosperous Society in All Respects 40 (People's Publishing House, 2012).

4 In the Fourth Plenary Session of the 18th CPC Central Committee, the resolution pointed out that "strengthening foreign-related legal affairs" will require China to "... actively participate in the making of international rules and regulations, and to promote the handling of foreign economic and social affairs according to law, strengthen our State's power of discourse and influence in international legal affairs, and to safeguard the sovereignty, security and development interests of our country by legal means." 


\section{Legal Problems in Contemporary Global Ocean Governance: Main Defects and Reformation}

With its inception in 1945, the UN began to build an ocean governance system for the post-war world. It convened three conferences on the law of the sea from 1958 to 1982 . This process established the contemporary global ocean governance system through the United Nations Convention on the Law of the Sea ("UNCLOS") in $1982^{5}$ and the Agreement Relating to the Implementation of Part XI of the UN Convention on the Law of the Sea of 10 December 1982 in 1994.

\section{A. The Main Defects of the Contemporary System}

The UNCLOS was signed as a result of struggle and compromise among different maritime interest groups of the international community. It reflected the common concerns and aspirations of all parties in the conferences. ${ }^{6}$ Nonetheless, the contemporary global ocean governance system has many defects.

\section{Blurred rules}

First, many rules of the UNCLOS and other relevant provisions are set in lawmaking treaties. Compared with contractual treaties whose regulations are stipulated in a more detailed fashion, the provisions of law-making treaties are general and ambiguous. It often leads parties to controversies due to differing interpretation. In fact, the UNCLOS fails to explicitly stipulate historical rights of maritime areas and features such as islands and reefs. For example, Articles 10, 15 and 298 of the UNCLOS do not clearly define 'historic bay,' 'historical waters,' or 'historic title.' Further, Article 121 (Part VIII) deals specifically with the "Regime of Islands," but fails to clear the cloud over the definition of either 'islands' or 'reefs,' let alone specific criteria for "maintaining human habitation or its own economic life." International

5 A. de Marffy, Ocean Governance: A Process in the Right Direction for the Effective Management of the Oceans, 18 OCEAN Y.B. 163 (2004).

6 T. Scovazzi, The Evolution of International Law of the Sea: New Issues, New Challenges, 286 RecueIL Des Cours (Collected Courses of The Hague Academy of International Law) 122 (2000).

7 J. Van Dyke \& R. Brooks, Uninhabited Islands: Their Impact on the Ownership of the Oceans' Resources, 12 OCEAN Dev. \& Int'L L. 286 (1983). See also Yann-huei Song, The Application of Article 121 of the Law of the Sea Convention to the Selected Geographical Features Situated in the Pacific Ocean, 9 CHINESE J. INT'L L. 679-80 (2010); J. Charney, Note and Comment: Rocks That Cannot Sustain Human Habitation, 93 Am. J. INT'L L. 868 (1999); Zewei Yang, On the Construction of the Maritime Silk Road in the 21st Century and the Reform of the International Marine Legal Order [论21世纪海上丝绸之路建设与国际海洋法律秩序的变革], 5 ORIENTAL L. [东方法学] 46-7 (2016). 
lawyers would interpret Article 121 differently. Jon M. Van Dyke, Robert A. Brooks and Northcut Ely argued that Article 121 of the Convention should be interpreted in such a strict way that rocks which cannot sustain the habitation and economic life of more than 50 people should have no exclusive economic zone ("EEZ") or continental shelf. ${ }^{8}$ Conversely, Jonathan Charney advocated a broad interpretation, arguing if only rocks can sustain either 'human habitation' or "economic life of their own," they should have their EEZs or continental shelf. ${ }^{9}$

Second, many provisions of law-making treaties are the result of a package deal in which vague and general provisions are employed in order to get all parties to agree and to balance competing interests. At the Third United Nations Conference on the Law of the Sea, for example, many countries agreed that foreign warships and military aircraft could pass through straits belonging to coastal states, but these rights were conditioned on agreement with the system of exploration and exploitation in the Area of the UNCLOS (i.e., the seabed and ocean floor and subsoil thereof, beyond the limits of national jurisdiction), as laid down in Part XI of the UNCLOS. ${ }^{10}$ Obviously, the above provisions are general principles which cannot solve the contradiction between the aforesaid two viewpoints.

For another example, there are two opposite views on the principle of delimitation of continental shelves between adjacent or opposite States. One is that the middle or equidistance line should be applied in the delimitation, based on the 1958 Convention on the Continental Shelf. The other is that the demarcation line should be made according to the equitable principle, as laid down in the North Sea Continental Shelf case. ${ }^{11}$ Meanwhile, Article 83 of the UNCLOS provides: "The delimitation of the continental shelf between States with opposite or adjacent coasts shall be effected by agreement on the basis of international law, as referred to in Article 38 of the Statue of the International Court of Justice, in order to achieve an equitable solution..."12 In this regard, these competing interests existed but were nevertheless ignored by the general and vague wording of the UNCLOS.

Finally, some rules of the current system just address political statements whose legal binding force is not enough strong. For example, in 2002, China and the Association of Southeast Asian Nations ("ASEAN") signed the Declaration on

8 Van Dyke \& Brooks, id. See also Song, id.

9 Charney, supra note 7.

10 UNCLOS ch. VII. For details, see H. Caminos \& M. Molitor, Progressive Development of International Law and the Package Deal, 79 Aм. J. InT'L L. 887-90 (1985).

11 North Sea Continental Shelf (F.R.G. v. Den.), Judgment, 1969 I.C.J. (Feb. 20), available at https://www.icj-cij.org/ files/case-related/51/051-19690220-JUD-01-00-EN.pdf (last visited on Oct. 30, 2018).

12 UNCLOS art. 83. 
the Conduct of Parties in the South China Sea to promote peace, stability, economic development, and prosperity in the South China Sea in order to bring about a peaceful, friendly, and harmonious environment in the region. ${ }^{13}$ However, the declaration has neither legal binding force on the parties, nor enforcement mechanism against the violation. ${ }^{14}$

\section{The Fragmentation of the global ocean governance mechanism ${ }^{15}$}

A new global ocean governance mechanism should be based on the cooperation of numerous regional and global organizations. ${ }^{16}$ At present, there are 12 important regional fisheries management organizations including the Commission for the Conservation of Antarctic Marine Living Resources ("CCAMLR"), International Commission for the Conservation of Atlantic Tunas, Indian Ocean Tuna Commission ("IOTC"), etc. In addition, the Southern Indian Ocean Fisheries Agreement 2006, the Convention Establishing the South Pacific Regional Fisheries Management Organization 2009, and the Convention on the Establishment of the North Pacific Fisheries Commission 2011 were adopted. Two regional fisheries organizations are under construction, as well.

Nonetheless, there is a lack of coordination among the organizations, ${ }^{17}$ some of whose functions overlap. In the area of marine environmental management, for instance, the International Seabed Authority ("ISA") published a "Discussion Paper on the Development and Drafting of Regulations on Exploitation for Mineral Resources in the Area (Environmental Matters)" (hereinafter Draft Environmental Regulation) in January 2017. ${ }^{18}$ This paper defines the environmental impact assessments of the "international seabed area," "environmental protection planning," "environmental planning review," and "remedial and punitive measures" in detail. ${ }^{19}$ As the ISA and

13 See Declaration on the Conduct of Parties in the South China Sea, available at https://www.mfa.gov.cn/web/wjb_ 673085/zzjg_673183/yzs_673193/dqzz_673197/nanhai_673325/t848051.shtml (last visited on Oct. 30, 2018).

14 Similarly, the "Guidelines for the Implementation of the DOC" signed by China and the ASEAN states in July 2011 are also a policy-type statement.

15 Yoshifumi Tanaka, Zonal and Integrated Management Approaches to Ocean Governance: Reflections on a Dual Approach in International Law of the Sea, 19 InT'L J. Marine \& CoAstal L. 506 (2004).

16 For details on the role of regional organizations in global ocean governance, see A. Soons, Implementation of the Law of the Sea Convention Through International Institutions, The 23rd Annual Conference of the Law of the SeA Institute Proc. 38-138 (1990); L. Juda, Rio Plus Ten: The Evolution of International Marine Fisheries Governance, 33 OCEAN DeV. \& INT'L L. 123-8 (2002).

17 Tanaka, supra note 15 , at 511-2.

18 ISA, Developing a Regulatory Framework for Mineral Exploitation in the Area (Environmental Matters) (2017), available at $\mathrm{https} / /$ www.isa.org.jm/files/documents/EN/Regs/DraftExpl/DP-EnvRegsDraft25117.pdf (last visited on Oct. 30, 2018).

19 Id. 
the Chamber of the ITLOS both involve in handling marine environmental issues, the de facto overlapping of their functions shall pose a challenge for future disputesettlement. $^{20}$

Fragmentation of the governance mechanism has led to some loopholes. For example, the UNCLOS divides the sea areas, according to geographic elements, into seven types such as internal waters, territorial sea, contiguous zone, EEZ, continental shelf, high seas, and international seabed areas and stipulates different legal systems for each. This fragmentation of management modes will inevitably create a vacuum in management content.

\section{B. Main Challenges and Development Trends}

\section{Emerging fields and problems in global ocean governance}

The conservation and use of biodiversity in waters beyond the national jurisdiction is a point of contention in the international community. In June 2015, the UN General Assembly adopted Resolution 69/292 to initiate international negotiation on the conservation and sustainable use of "marine biological diversity of areas beyond the national jurisdiction." ${ }^{, 21}$ Resolution 69/292 proposed a roadmap in three steps: (1) establishment of a preparatory committee; (2) an intergovernmental conference to start the formal negotiation process; and (3) introduction of an international agreement on the subject. ${ }^{22}$

In July 2017, the fourth meeting of the preparatory committee submitted the final proposal (draft) to the General Assembly. ${ }^{23}$ The draft aims to define the overall objectives and main contents of "marine biological diversity of areas beyond national jurisdiction. ${ }^{24}$ For this purpose, it should redefine the proprietary nature of marine biological resources which impacts the "principle of freedom of the high seas" and

20 For details on the Chamber for Marine Environment Disputes, see Seabed Disputes Chamber and Ad Hoc Chambers of the Seabed Disputes Chamber, available at https://www.itlos.org/the-tribunal/chambers (last visited on Oct. 30, 2018).

21 See Development of an international legally-binding instrument under the United Nations Convention on the Law of the Sea on the conservation and sustainable use of marine biological diversity of areas beyond national jurisdiction, G.A. Res. 74(a), U.N. Doc. A/RES/69/292 (June 19, 2015), available at http://www.un.org/en/ga/search/view_doc. asp?symbol=A/RES/69/292 (last visited on Oct. 30, 2018).

22 Zewei Yang (ed.), International Law [国际法] 173 (Higher Education Press, 3d ed. 2017).

23 See Report of the Preparatory Committee established by General Assembly resolution 69/292: Development of an international legally binding instrument under the United Nations Convention on the Law of the Sea on the conservation and sustainable use of marine biological diversity of areas beyond national jurisdiction, U.N. Doc. A/ AC.287/2017/PC.4/2 (2017), available at https://documents-dds-ny.un.org/doc/UNDOC/GEN/N17/237/36/PDF/ N1723736.pdf (last visited on Oct. 30, 2018).

24 Id. at 8 . 
"the state's principal status in the contemporary global ocean governance system." 25 The draft also indicates that new rules and systems for global ocean governance are in consideration. ${ }^{26}$

As another example, current international seabed activities have reached a historic turning point - from exploration to the preparation for exploration and development. ${ }^{27}$ As large-scale commercial development of the international seabed is underway, it is imperative to formulate an 'Exploitation Code' to establish a framework for the future development of mining areas. For this purpose, the ISA promulgated the "Working Draft Regulations and Standard Contract Terms on Exploitation for Mineral Resources in the Area" (hereinafter Draft Exploitation Regulations) in July $2016^{28}$ and then released the above mentioned Draft Environmental Regulations in January 2017. ${ }^{29}$ Inasmuch as having great differences of interest in the "exploitation regulations" and "environmental regulations," the stakeholders cannot reach consensus on the three core issues, namely, charge, environmental protection, and confidentiality of information. It will take time to adopt an Exploitation Code. A major challenge for the ISA is to formulate a scientific, fair, and equitable Exploitation Code for international seabed regional resources. This is another problem that global ocean governance must face today.

\section{Nontraditional security}

On the one hand, maritime terrorism is becoming more serious than before. ${ }^{30}$ The Islamic State, despite its decline in Iraq and Syria threatens to carry out terrorist operations wherever it finds an opportunity, which may be transferred to the sea. On the other hand, the impact of climate change on global ocean governance is attracting more attention from the international community. ${ }^{31}$

25 Id. at 17.

26 CiMA (ed.), China's OCEAn Development Report [中国海洋发展报告(2018)] 4 (2018)

27 Y ANG, supra note 22, at 177.

28 ISA, Working Draft Regulations and Standard Contract Terms on Exploitation for Mineral Resources in the Area, available at $\mathrm{https}: / /$ www.isa.org.jm/files/documents/EN/Regs/DraftExpl/Draft_ExplReg_SCT.pdf (last visited on Oct. 30, 2018).

29 Supra note 18.

30 Xiaofeng Xu \& Zhijiang Wei (eds.), Report on China’s Non-traditional Security Studies (2015-16) [中国非传统安全 研究报告 (2015-16)] 160-73 (Social Science Academic Press, 2016).

31 R. Craig, Ocean Governance for the 21st Century: Making Marine Zoning Climate Change Adaptable, 36 Harv. EnVtL. L. Rev. 305-50 (2012), available at http://harvardelr.com/wp-content/uploads/2012/09/Craig.pdf (last visited on Oct. 28, 2018). See also E. Kirk, The Ecosystem Approach and the Search for An Objective and Content for the Concept of Holistic Ocean Governance, 46 OcEAn Dev. \& INT'L L. (2015). 


\section{Maritime questions}

The principle of freedom of navigation involves not only public legal questions, such as the innocent passage of a state's warship in another state's territorial sea or activities in another state's EEZ, but also private ones, such as the international carriage of goods by sea. Freedom and safety of navigation are in accordance with combating terrorism and piracy at sea. It is also closely related to establishing and constructing offshore oil and gas drilling platforms, which affect the delimitation of the continental shelf and the exploitation of resources in deep seabed. The question of marine environmental protection runs through the whole process. ${ }^{32}$

\section{Waters beyond national jurisdiction}

Today, the global ocean governance system is "continuous[ly] strengthening [the maritime] areas beyond national jurisdiction," such as the legislative process of "international agreement on marine biological diversity of areas beyond national jurisdiction," the determination of the legal status of deep-sea genetic resources, the formulation of the Exploitation Code for the international seabed, the construction of the legal system for high seas reserves, etc. ${ }^{33}$ In practice, marine reserves can be established within the maritime jurisdiction of the state or in the high seas. Currently, there are four main high seas reserves on the earth, although some international organizations and non-governmental organizations ("NGOs") have proposed dozens of other potential preferred high seas reserves, such as the Sayedmahleha Shoal in the Indian Ocean east of Madagascar. ${ }^{34}$ The establishment of high seas reserves has become an effective way for the international community to protect marine resources beyond the jurisdiction of the state.

\section{Perfection of the Contemporary System}

As mentioned earlier, the contemporary global ocean governance system is based on the UNCLOS, which is regarded as the "Constitution for the Oceans." This, however, makes it hard to solve the newly arising ocean problems in a brand new and innovative manner. It is thus necessary to improve the existing system at both international and regional levels.

32 CIMA, supra note 26, at 239-44.

33 YANG, supra note 22, at 181.

34 K. Gjerde \& C. Breide (eds.), Towards a Strategy for High Seas Marine Protected Areas, The iUCN, WCPA and WWF Experts Workshop on High Seas Marine Protected Areas Proc. 15-7 (2003), available at http://cmsdata.iucn. org/downloads/towards_a_strategy_for_hsmpas.pdf (last visited on Oct. 30, 2018). 


\section{International level}

First, the current annual review conference of the UN General Assembly on the issue of oceans and the law of the sea relies primarily on the reports of the UN SecretaryGeneral and the proposals of the "Open-Ended Informal Consultative Process on Oceans and the Law of the Sea." 35 Moreover, this annual review conference only occasionally discusses the development of national ocean policies and the UNCLOS. ${ }^{36}$ Therefore, in accordance with Articles 312 and 313 of the UNCLOS, a review mechanism of the UNCLOS should be established and improved. ${ }^{37}$

Second, a supplementary agreement of special nature should be concluded. For example, the Agreement relating to the Implementation of Part XI of the United Nations Convention on the Law of the Sea 1994 and the United Nations Agreement for the Implementation of the Provisions of the United Nations Convention on the Law of the Sea of 10 December 1982 relating to the Conservation and Management of Straddling Fish Stocks and Highly Migratory Fish Stocks 1995, respectively, have amended Part XI of the UNCLOS and the principle of freedom of fishing on the high seas and other issues related to global ocean governance. ${ }^{38}$ Another example is the Exploitation Code, which is under promotion by the ISA. It will further improve the global ocean governance system. ${ }^{39}$ Today, the international seabed activities are turning from exploration to development. As large-scale commercial development of the international seabed become feasible, developing the Exploitation Code and building an institutional framework for future mining are important task for the ISA in the next few years. The new regime on the development of resource of international seabed will further improve the global ocean governance system.

Finally, relevant international organizations should be guided to improve the system. Maribel Aguilos suggested that in view of the complexity of the global ocean governance and the important role of the UN, the UN Charter should be modified to upgrade "global ocean governance" to the same status as the other purposes of the

35 UNCLOS art. 313. It provides: "A State Party may, by written communication addressed to the Secretary-General of the United Nations, propose an amendment to this Convention, other than an amendment relating to activities in the Area, to be adopted by the simplified procedure set forth in this article without convening a conference. The SecretaryGeneral shall circulate the communication to all States Parties."

36 CIMA, supra note 26, at 33.

37 T. Koivurova, A Note on the European Union's Integrated Maritime Policy, 40 OcEan Dev. \& InT'L L. 172 (2009) available at $\mathrm{https}: / /$ www.researchgate.net/publication/248921851_A_Note_on_the_European_Union's_Integrated Maritime_Policy (last visited on Oct. 28, 2018).

38 J. Harrison, Making the Law of the Sea: A Study in the Development of International Law 85-114 (2011).

39 Zewei Yang, The Development of the Exploitation Code in the Area and China's Position [国际海底区域 “开采法典” 的制定与中国的应有立场], 32:2 CONTEMP. L. REv. [当代法学] 26-34 (2018). 
UN, such as "to maintain international peace and security." 40

\section{Regional level}

In 2004, 16 Asian states concluded the Regional Cooperation Agreement on Combating Piracy and Armed Robbery against Ships in Asia ("ReCAAP"), ${ }^{41}$ which specifically defines "armed robbery against ships." ${ }^{, 2}$ ReCAAP applies not only to piracy on the high seas or in an EEZ, but also to 'armed robbery' in territorial waters, archipelago waters, and straits used for international navigation. Consequently, ReCAAP filled gaps in the UNCLOS ${ }^{43}$ and improved the global ocean governance system.

\section{China's Participation in the Global Ocean Governance Reform: Its Experiences and Lessons}

\section{A. China's Basic Principles in Ocean Policy}

By participating in the global ocean governance reform process, China has formulated principles in ocean policy. First, China has consistently defended its maritime rights in accordance with the principles of sovereign equality, noninterference in another nation's internal affairs, and peaceful settlement of international disputes. ${ }^{44}$ In addition, China has also respected the basic principle of international law of the sea in resolving territorial sea disputes and maritime delimitation issues through direct negotiation and consultation with the parties concerned. ${ }^{45}$

Second, along with China's participation in the global ocean governance reform, its domestic maritime law system has gradually improved. Since the 1980s, China has

40 M. Aguilos, Toward Integrated Ocean Management and Development, 12 WorLd BulL. 121 (1996).

41 See ReCAAP Information Sharing Center, available at http://www.recaap.org (last visited on Oct. 30, 2018).

42 ReCAAP art. 1(2).

43 R. Collins \& D. Hassan, Applications and Shortcomings of the Law of the Sea in Combating Piracy: A South East Asian Perspective, 40 J. Mar. L. \& Com. 15 (2009). See also Zewei Yang (ed.), China's Legal Guarantee for the SAFETy of MARItime ENergy Routes [中国海上能源通道安全的法律保障] 134-8 (Wuhan Univ. Press, 2011).

44 Yi Wang, China is a firm defender and builder of the international rule of law [中国是国际法治的坚定维护者和建 设者], GuANGming DaILY [光明日报], Oct. 24, 2014, at 1 .

45 See Statement of the Ministry of Foreign Affairs of the People's Republic of China on the award of the South China Sea Arbitration Tribunal established at the request of the Republic of the Philippines [中华人民共和国外交部关于应 菲律宾共和国请求建立的南海仲裁案仲裁庭所作裁决的声明] (July 12, 2016), available at http://www.fmprc.gov. cn/nanhai/chn/snhwtlcwj/t1379490.htm (last visited on Oct. 30, 2018). 
adopted a series of decrees, ordinances, regulations, and rules concerning territorial seas, EEZs, continental shelf, straits, port management, ship management, prevention of marine pollution, and protection of aquatic resources. ${ }^{46}$ In particular, China ratified the UNCLOS in 1996, which helped China adapt to the contemporary global ocean governance system and safeguard its maritime interests more effectively under international law. It has made a wide and far-reaching influence on China's marine legislation, ocean policy and commerce. ${ }^{47}$

Further, following prospective regulations of the ISA and the legislative process of the Exploitation Code, the Standing Committee of the National People's Congress of China passed the Law of the People's Republic of China on the Exploration and Development of Resources in Deep Seabed Areas in $2016 .{ }^{48}$

All these not only contribute to the implementation of China's marine strategy, but also facilitate its further participation in the global ocean governance reform.

\section{B. Lessons from China's Participation}

China has so far been a passive recipient of international rules in ocean governance "perform[ing] fairly well." Actually, "new rules initiated by China are very few." 49 Take the Third United Nations Conference on the Law of the Sea as an example. China's played little role in setting the agenda. It did not put forward proposals, but supported demands of most developing countries. ${ }^{50}$ In the process of drafting the convention, China was not arguing its legal position enough mainly because there were few ocean law experts. ${ }^{51}$ The number of ocean law experts in the Chinese delegation was smaller than those of medium-sized countries such as Denmark and Switzerland. They were even unfamiliar with the procedural rules of the conference. ${ }^{52}$

46 Office of Policy, Law and Regulation of the State Oceanic Administration (ed.), Collection of the Sea Laws and Regulations of the People's Republic of China [中华人民共和国海洋法规选编] (Ocean Press, 3d ed. 2011).

47 JingXI Hua, A CourSe OF THE LAW OF THE SEA [海洋法学教程] 461-72 (China Ocean Univ. Press, 2009).

48 See the Law of the People's Republic of China on the Exploration and Development of Resources in Deep Seabed Areas [中华人民共和国深海海底区域资源勘探开发法], available at http://www.gov.cn/zhengce/2016-02/27/ content_5046853.htm (last visited on Oct. 30, 2018).

49 A. Johnston, China and International Organizations: perspectives from outside China, in CONSTRUCTION IN Contradiction: Multi-dimensioned Perspectives on China's Relations with International Organizations [合中的建 构 - 中国与国际组织关系的多视角透视] 351 (Yizhou Wang ed., 2003).

50 Hungdah Chiu, China and the Law of the Sea Conference, 4 Occasional Papers/Reprints Series in Contemporary Asian STUdies 25 (1981).

51 Huiqing Chen, China and the Convention on the Law of the Sea: Historical Review, Experiences and Lessons [国与< 海洋法公约>: 历史回顾与经验教训], 3 WuHAN U. INT’L L. REv. [武汉大国际法评论] 127 (2017).

52 Id. at 115-28 (2017). See also Degong Chen, Recent International LaW of the SeA [现代国际海洋法] 530-2 (Ocean Press, 2009). 
Although the Chinese delegation participated in all the sessions from the beginning to the end, the delegates failed to showcase a Chinese brand to the global ocean governance forum. ${ }^{53}$ John Ikenberry said that emerging powers like China did not experiences in building a global order, so that they could not put forward a viable alternative model. ${ }^{54}$ Due to the low profile participation in establishing and reforming the global ocean governance system, China could not actively defend its maritime rights.

China has so far stood on the side of the developing countries and unilaterally supported their positions on an ideological ground. Today, however, China should consider its own maritime rights and interests more than an ideological principle. Shizhong Done has pointed out:

This is the first time that my delegation has attended a large-scale multilateral lawmaking conference like the Third UN Conference on the Law of the Sea. However, as a socialist country with a billion people who has always stood on the side of the Third World countries, our principled position on the main issues of the law of the sea is a huge boost in developing countries. ${ }^{55}$

China has now become an active participant and contributor to international seabed affairs. Chinese entities have long been 'pioneer investors' in polymetallic nodule resources in the international seabed and obtained four exclusive exploration areas therein. ${ }^{56}$ Given the current situation, conventional positions backing up developing countries would not be always in line with China's national interests today.

Further, China has firmly supported the EEZ system advocated by developing countries such as Latin America and Africa. However, China is a country with an unfavorable marine geography. In this case, the EEZ system put forward by developing countries would not always do good to China, who has newly expanded ocean use. To sum up, China's ideological position is neither entirely in line with its national footing, nor conducive to the protection of ocean rights and interests. ${ }^{57}$

Finally, China should strike balance between its national interests (short-term and long-term) and the global ocean governance rules, because some of the global

53 Chen, id. 521-42.

54 J. Ikenberry, The Future of the Liberal World Order, 90:3 ForeIGn AfF. 56-68 (2011).

55 Shizhong Dong, China's Principled Stand at the Third Session of the United Nations Conference on the Law of the Sea [我国在第三次联合国海洋法会议上的原则立场], in TheORY AND Practice OF CONTEMPORARY Marine LAw [当代海 洋法的理论与实践] 1 (Lihai Zhao ed., 1987).

56 Cima (ed.), China's Ocean Development Report 128 (Ocean Press, 2017).

57 CHEN, supra note 52. 
rules could prevent the implementation of its ocean policy and law. For example, there has been a controversy in international law as to whether warships enjoy a right of innocent passage through territorial seas. ${ }^{58}$ Practices would vary from country to country. At the Third UN Conference on the Law of the Sea, there were obvious differences between the major maritime powers such as the US and the then Soviet Union, and the developing countries including China. Traditionally, China has always held that warships could not enjoy innocent passage in foreign territorial seas. $^{59}$

However, Lihai Zhao maintained a different position: He said: “..., according to the principle of reciprocity, requiring foreign warships to pass through the territorial sea with prior consent, may not be beneficial to our country." As for the innocent passage of warship in other country's territorial sea, China has maintained two different positions. One is to give priority to military security based on the unforgettable humiliation of 'gunboat diplomacy, ${ }^{61}$ while the other is to consider the national strategy for building a marine power. If foreign warships enjoy the right of innocent passage through China's territorial waters, Chinese navy can go global more easily, thereby safeguarding China's expanding maritime rights and interests more efficiently. $^{62}$

Given the recent situation, traditional approach to the warship's innocent passage through other country's territorial water (consent of or prior notice to other country) could be inconsistent with the national stance of China to be a global ocean power. ${ }^{63}$

The resources in the EEZ is another question. With the rapid development

58 R. Pedrozo, Preserving Navigational Rights and Freedoms: The Right to Conduct Military Activities in China's Exclusive Economic Zone, 9 CHINESE J. INT'L L. 9 (2010). See also Haiwen Zhang, Is It Safeguarding the Freedom of Navigation or Maritime Hegemony of the United States?-Comments on Raul (Pete) Pedrozo's Article on Military Activities in the EEZ, 9 ChINESE J. INT'L L. 47 (2010); E. Franckx, American and Chinese Views on Navigational Rights of Warships, 10 CHINESE J. INT'L L. 187-206 (2011).

59 The Statement of the Government of the People's Republic of China on Territorial Waters (Sept. 4, 1958). It specifies: "All foreign aircraft and military vessels shall not enter China's territorial waters and airspace without the permission of the Government of the People's Republic of China." See Peking University's teaching and research section of international law (ed.), Data Compilation of the Law of the Sea [海洋法资料汇编] 84 (People's Publishing House, 1974).

60 Lihai Zhao, Issue of ratification of the United Nations Convention on the Law of the Sea [联合国海洋法公约>的批准 问题], 4 J. Peking U. (Humanities \& Social Sci.) [北京大学学报(哲学社会科学版)] 59 (1991).

61 Zhang, supra note 58, at 31-48.

62 J. Root, The Freedom of Navigation Program: Assessing 35 Years of Effort, 43 Syracuse J. InT'L L. \& Com. 322-33 (2016). See also Zewei Yang, The Freedom of Navigation in the South China Sea: An Ideal or a Reality?, 3:3 BeIJNG L. REv. 136-43 (2012).

63 Chiu, supra note 50. See also Faqiang Yuan, Contemporary Freedom of Navigation System and China's Policy Choice, 4 China InT’L Stud. 133-56 (2016). 
of pelagic fishery in the 21st century, ${ }^{64}$ Chinese fishing boats and fishermen have been often detained by other countries, which used to make fishery disputes with Indonesia, Korea, etc. ${ }^{65}$ It can be seen that China's e claims are in conflict with its long-term interests. ${ }^{66}$

Regarding the deep seabed area, China advocates that only the ISA can develop and manage resources there. Such single development system may obviously pose a constraint to the country in the development of international seabed resources. Under the current position, China is not qualified to participate in the development, let alone be the 'pioneer investor' with the largest number of mining areas.

In conclusion, China lacks strategic thinking on the long-term interests in establishing and reforming the ocean governance system. It should recognize that some rules could shackle China's ocean development itself.

\section{China's Participation in the Global Ocean Governance Reform in the New Era ${ }^{67}$}

\section{A. National Identity}

China began to participate in the global ocean governance reform as a developing country. ${ }^{68}$ Today, however, China's international standing has improved considerably.

64 In 2006, China began subsidizing pelagic fisheries, which promoted their rapid development. The number of pelagic fishing vessels increased by nearly 45 percent from 2007 to 2014. See Chun Zhang, China's maritime strategy at the moment and far away, Fin. Times, July 18, 2017, recited from REFERENCE NEWs, July 19, 2017, at 10.

65 Zewei Yang, The Present and Future of the Sino-South Korean Fisheries Dispute: A Chinese Lawyer's Perspective, 5 J. EAST ASIA \& INT’L L. 479-93 (2012).

66 For the resources of EEZ, China's position is that "the renewable and non-renewable resources in the seas adjacent to coastal countries are an integral part of the natural resources of coastal countries and an important condition for their economic development... Today, the vast majority of developing countries declare permanent sovereignty over their coastal resources, which is their legitimate rights and interests and should be respected by other countries..." See Speech by Comrade Qing Ling on the second committee on the exclusive economic zone (Aug. 1, 1974) [凌青同志在第二委 员会关于专属经济区问题的发言(1974年8月1日)], in File SET OF My Delegation's Attendance at Relevant United NAtions Conferences And MeEtings (July-December, 1974) [我国代表团出席联合国有关会议文件集 (1974.7-12)] 292-3 (People's Publishing House, 1975). However, with the rapid development of China's pelagic fishery in the 21st century, Chinese fishing boats and fishermen have been repeatedly detained by other countries, and fishery disputes between China and Indonesia, South Korea and other countries are increasing.

67 China entered into a 'New Era' from 2012, after the Eighteenth National Congress of the Communist Party of China. See The Report of the Nineteenth National Congress of the Communist Party of China 2017.

68 Yixian Xie (ed.), History of Contemporary Chinese Diplomacy (1949-2009) [中国当代外交史(1949-2009)] 458 (China Youth Press, 2009). 
The ocean is the fundamental ground for China's future development. In May 2017, China hosted the first Annual Meeting of the States Parties to the 'Antarctic Treaty,' which indicated the influential role of China in global ocean governance from a 'runner-up' to a 'pacemaker. ${ }^{69}$ Today, China's marine interests have expanded from the original geographic aspect to the international institutional level.

\section{B. China is a Newly Invigorated Player! ${ }^{70}$}

The institutional design of China's participation in the global ocean governance reform includes the following two aspects. One is to launch a World Ocean Organization and the other is to transform the global ocean governance system.

\section{World Ocean Organization}

As there are specific international organizations to lead the current global ocean governance system, China could launch the World Ocean Organization ("WOO"). First, the WOO can address fragmentation of the current governance mechanism ${ }^{71}$ and achieve the goal of "good governance of the oceans.",72 Second, the WOO will be the steppingstone of China's participation in transforming the global ocean governance system. ${ }^{73}$ It would be beneficial to share China's ideas with its allies. ${ }^{74}$

The WOO aims to build a 'harmonious ocean' and to realize sustainable development of ocean use. It would reflect the typical three-tier structure. ${ }^{75}$ First, the General Assembly is the supreme organ of the WOO, composed of government representatives from member states. It has the authority to formulate policies, adopt budgets, conduct elections, make recommendations, and supervise implementation. ${ }^{76}$ Second, the Council is the executive organ composed of representatives of core member states elected by the General Assembly. It is responsible for implementing

69 CIMA, supra note 26, at 264.

70 C. Norchi, China and the Public Order of the Oceans, 17 Ocean \& COASTAL L. J. 197 (2012), available at https:// digitalcommons.mainelaw.maine.edu/oclj/vol17/iss2/3 (last visited on Oct. 30, 2018).

71 Tanaka, supra note 15, at 511-2.

72 Marffy, supra note 5, at 162-3. See also J. van Ettinger, A. King \& P. Payoyo, Ocean Governance and the Global Picture, 33:7 World Bull. 44-5 (1991).

73 Id.

74 Zhongying Pang, China's Role in Global Governance [全球治理的中国角色] 5 (People's Publishing House, 2016).

75 Liang Xi (amended by Zewei Yang), Liang's International Organization LaW [梁著国际组织法] 291 (Wuhan Univ. Press, 2011).

76 According to the general rules and its powers of international organization, the General Assembly is the supreme organ of the WOO. For details, see H. Schermers \& N. Blokker, International Institutional Law: Unity within Diversity 389-442 (4th ed. 2003); J. KlabBers, An Introduction to International Institutional Law 154-60 (2d ed. 2009). 
the resolutions of the General Assembly and putting forward work measures. ${ }^{77}$ Third, the Secretariat is responsible for the administration of the organization. It can set up special offices regarding Marine Safety, Marine Resources Development, Marine Environmental Protection, and Marine Sustainable Development. ${ }^{78}$

The WOO may have two voting systems: the majority vote and consensus. Guoqing Jiang defines 'consensus' as "an informal practice of reaching a general agreement without voting on the basis of extensive consultation among member States, when formal voting rules are unsatisfactory or effective decisions cannot be made on the basis of them." ${ }^{, 79}$ The General Assembly could adopt a consensus decision-making process.

\section{Micro-level paths}

The micro-level path of China's participation in the global ocean governance system reform can include the following steps. First, in international treaty-making over the years, China only played the role of a contestant. ${ }^{80}$ In the future, however, China should not only participate in the formulation of rules, but also actively promote its own position into each issue. Second, in drafting treaties, China should maintain high morality respecting global common good. "Care for others and benefit myself" is the best way to strike the balance between national interests and the mutual concern of the international community. Finally, China should coordinate different interests of the international community. In addition to developing countries, China should make joint progress with developed countries in dealing with the reform process. In the development of deep seabed or the maintenance of freedom of navigation, for example, China has common interests with the US, Russia, Japan, France, and Germany, because they all demand the Exploitation Code to protect the interests of all pioneer investors and exploration contractors for the development of resource of the Area.

China is one of the few countries able to formulate international customs of ocean

77 Id.

78 Id.

79 Guoping Jiang, Legal System of the Specialized Agencies of the United Nations [联合国专门机构法律制度研究] 212 (Wuhan Univ. Press, 1993).

80 Some scholars have pointed out: "China is not the maker of the agenda. China often responds to bills submitted by other countries. In fact, the passive performance of China surprised the diplomats of developing countries. China rarely offers constructive solutions at the UN General Assembly or the Security Council." See A. Johnston, A General Explication of US Scholarship concerning China's Relationship with International Organizations, 8 WORLD ECON. \& Politics 49 (2001). 
governance. ${ }^{81}$ Lingliang Zeng pointed out: "Domestic judicial decisions, especially those involving or applying rules of international law, constitute an integral part of State practice and are important evidence for the formation and development of customary international rules. ${ }^{~} 82$ In the course of handling maritime cases, China's judicial organs are inevitably involved in applying and identifying principles of the contemporary global ocean governance system together with China's domestic law.

It is worth noting that the Provisions of the Supreme People's Court on Several Issues concerning the Trial of Relevant Cases Occurring in Sea Waters under the Jurisdiction of China (I) and the Provisions of the Supreme People's Court on Several Issues Concerning the Trial of Relevant Cases Occurring in Sea Waters under the Jurisdiction of China (II) came into effect on August 2, 2016. ${ }^{83}$ They are important ground to safeguard China's maritime rights and to form international customary rules concerning the global ocean governance system.

Although China is a permanent member of the UN Security Council, it has been passive in international rule-making. ${ }^{84}$ As international organizations have been playing an active role in ocean governance, China should work with intergovernmental organizations for the reform. In particular, China should be familiar with the procedures of international judicial institutions.

In addition, NGOs are actively transforming the global ocean governance system. ${ }^{85}$ NGOs have been recognized in the negotiation process of the UNCLOS and the International Agreement on Marine Biological Diversity beyond National Jurisdiction. ${ }^{86}$ In the international community, NGOs would diversify the value of lawmaking process. ${ }^{87}$ Hence, China's NGOs should participate in international legislations. They are required to make a joint effort with the government, which is conducive to China's in-depth participation in the reform of the global ocean

81 Min Gyo Koo, Belling the Chinese Dragon at Sea: Western Theories and Asian Realities, 48 OcEAn Dev. \& INT'L L. 63 (2017).

82 Lingliang Zeng (ed.), International Law [国际法学] 19 (China Social Sciences Press, 2003).

83 See Provisions of the Supreme People's Court on Several Issues Concerning the Trial of Relevant Cases Occurring in Sea Waters under the Jurisdiction of China (I), China Maritime Trial (Oct. 26, 2016), available at http:/enccmt.court. gov.cn/chinamaritimetrial/2016-10/26/c_59502.htm (last visited on Oct. 18, 2018).

84 Yizhou Wang, Global Politics and China's Foreign Policy: Exploring new Perspectives and explanations [全球政 治和中国外交: 探寻新的视角与解释] 254 (World Affairs Press, 2003).

85 R. Parmentier, Role and Impact of International NGOs in Global Ocean Governance, 26 OCEAN Y.B. 211 (2012). See also G. Hewison, Role of Environmental Nongovernmental Organizations in Ocean Governance, 12 OCEAN Y.B. 32 (1996).

86 Parmentier, $i d$. at 214.

87 Tuo Cai \& Zhenye Liu (eds.), The Construction of Global Science and Global Governance [全球学的构建与全球 治理] 258-9 (CUPL Press, 2013). 
governance system. China's ultimate aim is to further enhance its voice in the future reform of global ocean governance.

\title{
V. Conclusion
}

Robert Keohane and Joseph Nye point out:

\begin{abstract}
Maritime issues are determined by naval forces or capabilities, as well as by egalitarian organizational procedures and confrontations between rich and poor countries. Oceans issues were determined as much by egalitarian organizational procedures and by confrontation between rich and poor nations as by naval power or oceans capabilities. ${ }^{88}$
\end{abstract}

While reviewing the development process of global ocean governance, we discover that hegemonic powers have been always in a dominant position in its establishment and reform. For example, the US has explicitly stated in "An Ocean Blueprint for the 21st Century" that "the United States uses its domestic management experience as an example of global Ocean governance." " In the "International Ocean Governance: An Agenda for the Future of Our Oceans," the EU has also positioned itself as "a strong global actor" trying to shape a governance model based on its experience. ${ }^{90}$

As China is a late-comer in global ocean governance, it had a limited role in reformation for a long period of time. It still lags in the setting of issues, discourse construction, and rule-making. There is a strong "European and American taste" in governance theoretically and practically.

Since 2013, China has tried to play a greater role in shaping and influencing it. In this regard, President Xi Jinping delivered a speech in Berlin in March 2014:

We will proceed from the righteousness of world peace and development, contribute Chinese wisdom for dealing with contemporary international relations, deliver Chinese solutions for improving global governance, and make our own contribution to the library.unt.edu/oceancommission/documents/full_color_rpt/000_ocean_full_report.pdf(last visited on Oct. 30, 2018).

90 See Joint Communication to the European Parliament, the Council, the European Economic and Social Committee and the Committee of the Regions, International ocean governance: an agenda for the future of our oceans (Nov. 10, 2016), available at https://ec.europa.eu/maritimeaffairs/sites/maritimeaffairs/files/join-2016-49_en.pdf (last visited on Oct. 30, 2018). 
response of human society to the challenges of the 21 st century. ${ }^{91}$

As shown in President Xi's speech, China's role in the current governance system is becoming clearer and firmer. ${ }^{92}$ On the one hand, China is required to further participate in reform as a G2 country. On the other hand, the international community highly expects China to play a greater role in such reform. ${ }^{93}$ The 21 st Century Maritime Silk Road initiative may construct a new marine order for the common safety of the sea and the joint development of marine resources. ${ }^{94}$ Chinese voices should be integrated into the global ocean governance reform to ultimately build the "Global Maritime Community.","5

President Xi Jinping emphasized the "openness, inclusiveness, cooperation, and win-win spirit" of the BRICS in a series of speeches at the BRICS Summit in Xiamen in September 2017. ${ }^{96}$ He also pointed to the direction for reform of the global ocean governance system. ${ }^{97}$ In this regard, China should uphold the harmony, common governance, and win-win spirit in order to build the "Global Maritime Community" for a just and reasonable system. Following the principles of joint discussion and co-construction, China should prevent the few maritime powers with superior geographic conditions from dominating global ocean governance system incompatible with the interests of all mankind.

91 See President Xi Jinping delivered a speech in Berlin in March 2014, available at http://www.gov.cn/xinwen/2014-03/ 29/content_2649512.htm (last visited on Oct. 30, 2018). See also Zhongying Pang, China's Role in Global Governance [全球治理的中国角] 143-4 (People's Publishing House, 2016).

92 PANG, id. at 4.

93 See Vision for Maritime Cooperation under the Belt and Road Initiative, available at https://www.yidaiyilu.gov.cn/ wcm.files/upload/CMSydylgw/201706/201706200153032.pdf (last visited on Oct. 30, 2018).

94 Jie Zhang (ed.), China’s Regional Security Environment Review: 2015 [中国周边安全形式评估: “一带一路” 与 周边战略(2015)] 6-7 (Social Science Academic Press, 2015).

95 See Strategic Think on the China's Participation in the Global Ocean Governance [中国参与全球海洋治理的战略思 考], available at http://www.oceanol.com/fazhi/201802/14/c74222.html (last visited on Oct. 30, 2018).

96 See Deepen the Partnership of BRICS and Open up A Brighter Future: A Speech Delivered by Jinping Xi at a Large Scale Meeting of Leaders from BRICs Countries in Xiamen (Sept. 4, 2017) [深化金砖伙伴关系、开辟更加光明未 来-在金砖国家领导人厦门会晤大范围会议上的讲话], available at https://www.fmprc.gov.cn/web/ziliao_674904/ zyjh_674906/t1489723.shtm (last visited on Oct. 30, 2018).

97 See Let the Light of the Cooperation of the BRICS Illuminate the Future-Interpretation of President Jinping Xi's Speech at the Meeting of Leaders from BRICs Countries in Xiamen [让金砖合作之光照亮未来一解读习近平主席在金砖国 家领导人厦门会晤的讲话], XINHUANET, Sept. 4, 2017, available at http://www.xinhuanet.com//world/2017-09/04/ c_1121604065.htm (last visited on Oct. 30, 2018). 
